\title{
Effect of Service Quality and Rates on Satisfaction and Loyalty of Customer Behavior at Fitness
}

\author{
Japhet Ndayisenga*, Tomoliyus \\ Faculty of Sports Sciences, Universitas Negeri Yogyakarta, Indonesia
}

Copyright $\odot 2019$ by authors, all rights reserved. Authors agree that this article remains permanently open access under the terms of the Creative Commons Attribution License 4.0 International License

\begin{abstract}
Purpose: Regular quality of service and tariffs are generally recommended to be important factors for maintaining customers. The purpose of this study was to determine the effect of service quality on service satisfaction and fitness customer behavior, to determine the effect of tariff on fitness customer behavior loyalty, to determine the effect of satisfaction on customer behavior loyalty at fitness. Design/methodology/approach: Type This study was a descriptive research with mixed methods (qualitative and quantitative). The subjects of this research were 85 Customers from two groups: UNY Family and outside the UNY taken by random sampling. Data analysis techniques using correlation and linear regression among indicators-variables, and between variables themselves with Software SPSS.21 and PLS-SEM. Findings: The results showed that there was a significant effect of service quality on satisfaction, the effect of service quality on behavior loyalty was largely indirect. The ticket prices have a negative effect on satisfaction and behavioral loyalty. Research limitations/implications: Although this study lacks generalizability, thus, service quality and tariffs are strong management instruments to help sports management. Practical implications-Thus, service quality and tariffs are strong management instruments to help sports management to decide the allocation of resources to increase customer satisfaction and loyalty. Originality/value: This study is the first to apply to explain career to the current situation in that fitness.
\end{abstract}

Keywords Service Quality, Tariff, Satisfaction, Loyalty

\section{Introduction}

The development of the service business world nowadays is so fast and the competition between companies is very great high, so that the companies are required to work more effectively and efficiently (Yildiz \& Kara, 2012) [1]. In the field of business, especially fitness has experienced a very rapid increasing, both in terms of quality and quantity in Yogyakarta. In terms of quality, it can be seen that the service quality, the suitability of the rates and facilities provided to customers Santos, J. (2003) [2]. Customers as users of equipment and services in making ticket purchases are much influenced by internal and external factors. These factors have a very large influence in influencing the decision process to buy a ticket or become regular customers at fitness.

In every event the competition is faced by most companies in various industries seems to be getting tighter, the struggle for getting the interesting places will affect their needs in the market Avourdiadou, S. \& Theodorakis, N.D. (2014) [3]. The company will get a place in the hearts of customers if everything offered is in accordance with what they want. Therefore a serious understanding of user behavior Kim, P. \& Han, J. (2013) [4]. A company in its activities becomes a mandatory thing to manage services properly, so in principle it requires professional management in marketing, operations and human resources, integration of these elements becomes the key of success of service companies in other to improve business performance.

Rapid development in all fields has brought changes in people's lives. Nowadays the community is getting smarter and more critical, both in thinking and carrying out an action R., Mahamad, O. \& Ramayah, T. (2010) [5]. This is a challenge and opportunity for organizations / institutions engaged in services. One of the institutions engaged in services is fitness, Yogyakarta State University on the side of Fitness. UNY Fitness has been created in 2008, besides it, there are already five (5) other fitness, which mean that there is already a competition between fitness clubs around UNY. From 2008 there was no research that matched the actual situation in UNY's fitness. UNY fitness staff is not yet informed whether the quality of services is very beneficial to customers.

The purpose of this study was (1) to determine the effect of Service Quality and Rates on Satisfaction and Loyalty of Customer Behavior at Fitness, (2) to determine the effect of tariff on fitness customer behavior loyalty, (3) to determine 
the effect of satisfaction on customer behavior loyalty at fitness.

This research was very important because the results showed the strong and weak points belong to UNY fitness club, so it will be an opportunity to improve it. Finally the information from this study was to help UNY fitness clubs to prepare for the competition and maintain the customers, not only fitness club but for all business owners such as development guidelines.

\section{Literature Review}

\subsection{Service Quality}

Quality of service is centered on efforts to meet customer needs and desires and the accuracy of delivery to offset customer expectations. Service quality is the expected level of excellence and control over the level of excellence to meet customer desires Christian Grönroos, (2001) [6]. Quality is the starting point in seizing market share so that the level of satisfaction not only needs to be maintained but also must be increased to face increasingly fierce competition Nguyen, N., \& Leblanc, G. (2001) [7]. Therefore the company is required to be able to mobilize, organize and coordinate the activities of various groups of professional, semi-professional and non-professional personnel, so that they can achieve the planned goals.

Customer satisfaction will be the basis for developing various models of buyer behavior Olorunniwo, F., Hsu, M. K., \& Udo, G. J. (2006) [8]. In addition, customer satisfaction is a guideline to direct the entire organization towards meeting customer needs so that it becomes a source of sustainable competitive advantage. Consumer satisfaction with the services provided by the company will be known when making a measurement and testing of consumers. Service at a satisfactory value if the service can meet the needs and expectations of consumers. Consumer satisfaction measurement is an important element in providing better, more efficient and more effective services. The use of service quality dimensions as a measuring tool that is expected by a company to determine the level of customer satisfaction.

Knowing the results of measuring customer satisfaction companies can prepare a strategy that will be applied in order to create consumer loyalty. In fact, customer satisfaction is often overlooked or not properly considered by every individual in the organization. From the perspective of the customer / consumer there are often so many complaints regarding product quality, prices that are too high Soteriou, A. C., \& Stavrinides, Y. (2000) [9]. Nowadays and in the future in line with the developments that occur, the level of public education is increasing; the way of thinking becomes more modern followed by an awareness of the importance of service quality. There are four determinants of service quality, which include direct evidence of equipment, staff, price and program. The aforementioned variables greatly influence customer satisfaction with the quality of services provided by the company and have an impact in trying to create customer loyalty. Variation in shape, quality and type depends on who, when and where the service is produced in this case the service provider can do three stages in quality control: 1 ) Investing, selecting and training good personnel. 2) Standardizing the service implementation process. 3) Monitor user satisfaction through a system of suggestions and complaints, consumer surveys so that poor services can be detected and corrected.

\subsection{Tariff}

Rates or prices are the first aspects that need to be considered by the seller in an effort to market their products, and in terms of buyer prices are one of the aspects that determine whether to buy or not. To determine the price level of an item a market test is usually carried out Nusair, K., Yoon, H. J., Naipaul, S., \& Parsa, H. G. (2010) [10], meaning that the price of the item to be determined can be accepted or not by the buyer. If it cannot be accepted, the price of the item can be immediately changed. Price is the amount of money (plus several products if possible) needed to get a number of combinations of products and services.

Determining of the price level is usually done by making a number of changes to test the market, does it accept or reject? If the market accepts the offer, then the price is appropriate. But if they refuse it, then the price needs to be changed as soon as possible. So there is a possibility of a wrong decision about the price decision taken by management. In decision making the determination of the tariff needs to be reviewed whether the goal is for the seller to set the price or price of the product. These objectives include Zineldin, M. (2006) [11]: 1) Increase sales 2) Maintain and improve market share 3) Price stabilization 4) Reach the investment return target 5) Reach maximum profit and so on.

\subsection{Customer Satisfaction}

Satisfaction has a very relative understanding, because the satisfaction of consumers is very dependent on each individual who feels it. Consumer satisfaction is basically closely related to meeting the needs of consumers themselves.Satisfaction is defined as post-consumption evaluation that an alternative chosen at least meets expectations. In short, these alternatives at least work as well as expected (Payne \& Frow, 2013) [12]. Dissatisfaction, of course, is the result of expectations that are confirmed negatively. In general, satisfaction is the feeling of being happy or disappointed someone who comes from a comparison between the impression on the performance (or results) of a product and its expectations Seth, N., \& Deshmukh, S. G. (2005) [13]. 
Consumers are people who receive the work of a person or organization, so only those who can determine the quality of what and only those who can convey what and how their needs. There are several important elements in quality that are set by consumers. Yeung, M. C. H., Ging, L., \& Ennew, C. T. (2002) [14]:

a) Consumers must be the top priority for organizations because the survival of the organization depends on the consumer.

b) Reliable consumers are the most important consumers. Reliable consumers are consumers who buy multiple times (repeat purchases) from the same organization.

c) Consumers who are satisfied with the quality of products or services purchased from an organization become important consumers. Therefore, customer satisfaction is very important.

d) Consumer satisfaction is guaranteed by producing high quality products. Satisfaction has implications for continuous improvement so that the quality must be renewed as long as consumers remain satisfied and loyal.

Consumers do have to be satisfied, because if they are not satisfied they will leave the company and become competitor consumers, this will cause a decrease in sales and in turn will cause a decrease in sales and will reduce profits and even losses Szmigin, I. \& Carrigan, M. (2001) [15].

\subsection{Loyalty Behavior}

Consumer loyalty can be used as a basis or benchmark in taking policies to add or reduce the value of products for consumers. Tiessen-Raaphorst, A. \& Broek, A. van den (2016). Where the company will obtain information from consumers that is about the activities of interpreting, processing, and storing information about products and brands. Therefore customer loyalty from consumers' confidence in making purchasing decisions. Consumer loyalty can show how much a consumer's support for the product or service offered by the company Pedragosa, V. \& Correia, A. (2009) [16].

On the other hand, consumer loyalty can prove the level of consumer confidence in the products or services offered by the company Parasuraman, A., Berry, L. L., \& Zeithaml, V. A. (1993) [17].

\subsection{Method and Material}

This is the descriptive research with mixed method qualitative and quantitative approaches. The population in this study was UNY fitness customers, amounting of 85 . The study sample was determined by random sampling . Data collection techniques used questionnaires. Data analysis techniques using PLS - SEM and SPSS. The research hope was to show the actual situation in UNY fitness through the below Indicators and variables :

(1) Equipment, (2) Staff, (3) Service, (4) Program the later are indicators for the Service Quality variable, however the Attitude was an indicator of Variable customer satisfaction at Fitness, in add more Participant and Behavior were the Loyalty indicators. Secondly the all variable (dependent and Independent) were the following below:

a. Service quality variable (X1): dependent variable

b. Tariff variable (X2): dependent variable

c. Variable customer satisfaction at Fitness (Y1): independent variable

d. Loyalty of customer behavior at Fitness (Y2): independent variable

The research model and hypothesis in this study can be described and explained:

\section{A. Research Hypothesis}

1. There is correlation between indicators and Variable.

2. There is correlation between dependent variable and independent variable.

3. There is linear regression between dependent variable and independent variable.

\section{B. The Research Structural Equation Modeling}

The diagram below will help us to find the correlation that will exist between the indicators and the variables, and secondly the correlation that will exist between the variables themselves as the research hypotheses demonstrated above in A.

This research structural equation modelling has four variables and eight indicators, 4 indicators (equipment, service, staff, and program) for the service quality variable; 2 indicators (behaviour and participant) for loyalty independent variable; one indicator attitude for satisfaction independent variable; one indicator price for tariff dependent variable all will be showed on the diagram below. 


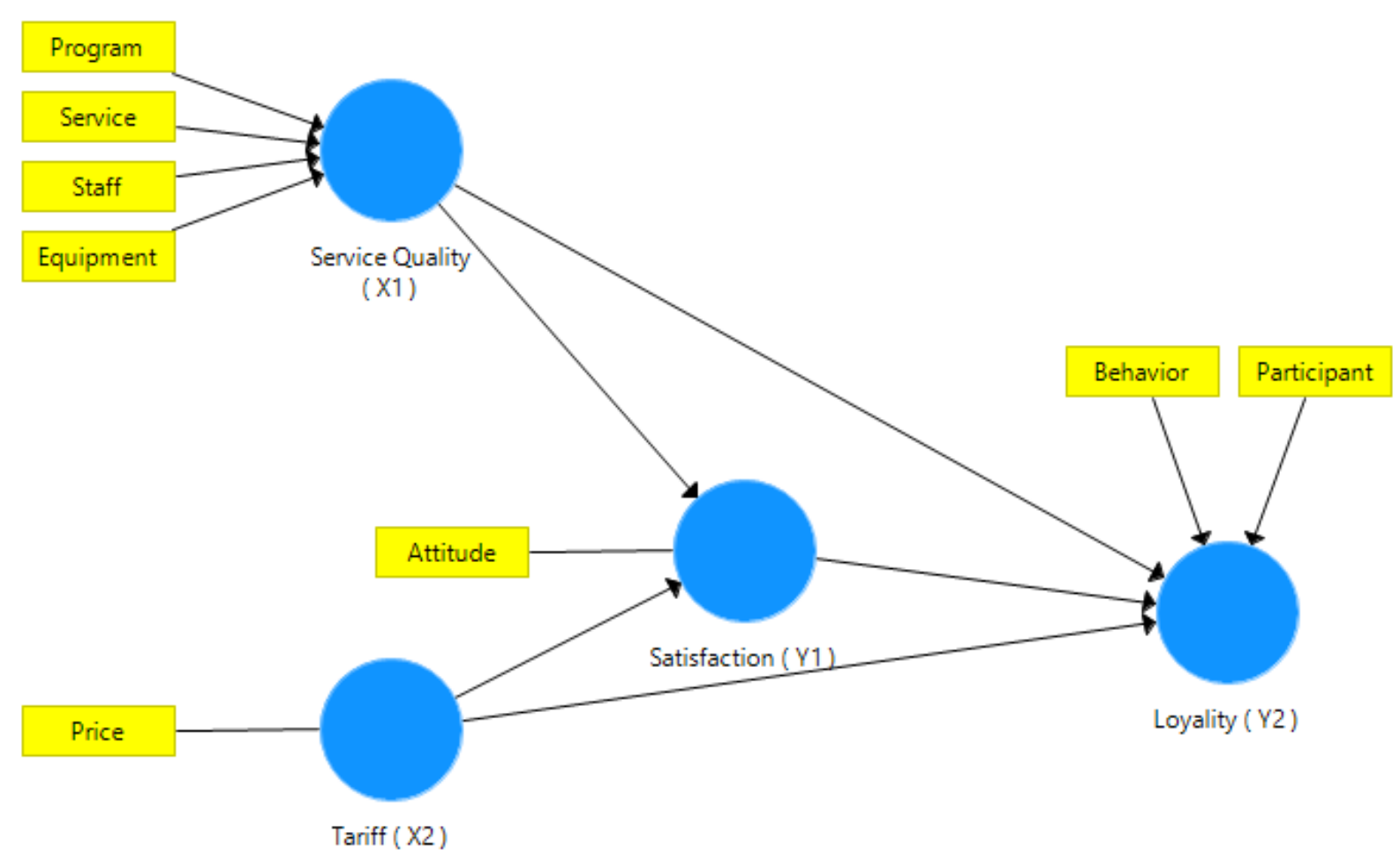

Diagram 1. The Research Structural Equation Modeling

Table 1. Internal consistency reliability (CR) and convergent validity (AVE).

\section{Construct Reliability and Validity}

\begin{tabular}{|c|c|c|c|c|c|c|c|c|}
\hline \multirow[t]{2}{*}{ Matrix } & 㩰言 & Cronbach's Alpha & 掉章 rho_A & 掉菲 & Composite Reliab & ility & 㩰萃 Averag & Variance Extracted \\
\hline & & Cronbach's Al... & \multicolumn{2}{|c|}{ rho_A } & Composite Rel... & \multicolumn{2}{|c|}{ Average Varian... } & \\
\hline \multicolumn{2}{|l|}{ Loyality } & 0.839 & \multicolumn{2}{|c|}{0.844} & 0.841 & & 0.726 & \\
\hline \multicolumn{2}{|c|}{ Satisfaction } & 1.000 & \multicolumn{2}{|c|}{1.000} & 1.000 & & 1.000 & \\
\hline \multicolumn{2}{|c|}{ Service Quality } & 0.478 & \multicolumn{2}{|c|}{0.622} & 0.480 & & 0.268 & \\
\hline Tariff & & 1.000 & \multicolumn{2}{|c|}{1.000} & 1.000 & & 1.000 & \\
\hline
\end{tabular}

\section{Result Research}

The result from this research has been presented and explanned such us:

In the Table 1: latent Variables Cronbach's Alpha rho-A Composite Reliability CR Average Variance Extracted(AVE). Reliability of internal consistency is assessed by evaluating of the combination reliability of all constructions. In our study, all composite reliability values were well above the 0.70 , expect to the service quality dependent variable in the first case, threshold, indicating that the combined reliability of each reflective latent variable was acceptable and confirmed construct reliability (Hair et al., 2014; Lowry \& Gaskin, 2014). See Table 1

Construct validity is the extent to which items measure
(Hair, Anderson, Tatham, \& Black, 1995, p. 641). To test construct validity, we tested convergent validity and discriminant validity. Convergent validity is the extent to which an AVE measure reflects the average communality for each latent factor (Garson, 2012), and must be 0.50 or higher (Hair et al., 2014). In our study, all AVE values above 0.50 , show dimensions and show that convergent validity of each latent factor is acceptable, except latent variable service quality. (Table 1 )

To assess collinearity, we consider the variance inflation factor (VIF). As can be concluded from Table 2, the VIF values in our study are well below the threshold value of 0.50 , indicating that collinearity is not a problem (Hair et al., 2011) 
Table 2. Collinearity Assessment (VIF).

\section{Collinearity Statistics (VIF)}

\begin{tabular}{|l|r|}
\hline Oniter VIF Values & VIF \\
\cline { 2 - 2 } Attitude & Inner VIF Values \\
\hline Behavior & 1.000 \\
\hline Participant & 2.091 \\
\hline Price & 2.091 \\
\hline Program & 1.000 \\
\hline Service & 1.058 \\
\hline Staff & 1.099 \\
\hline Equipment & 2.103 \\
\hline
\end{tabular}

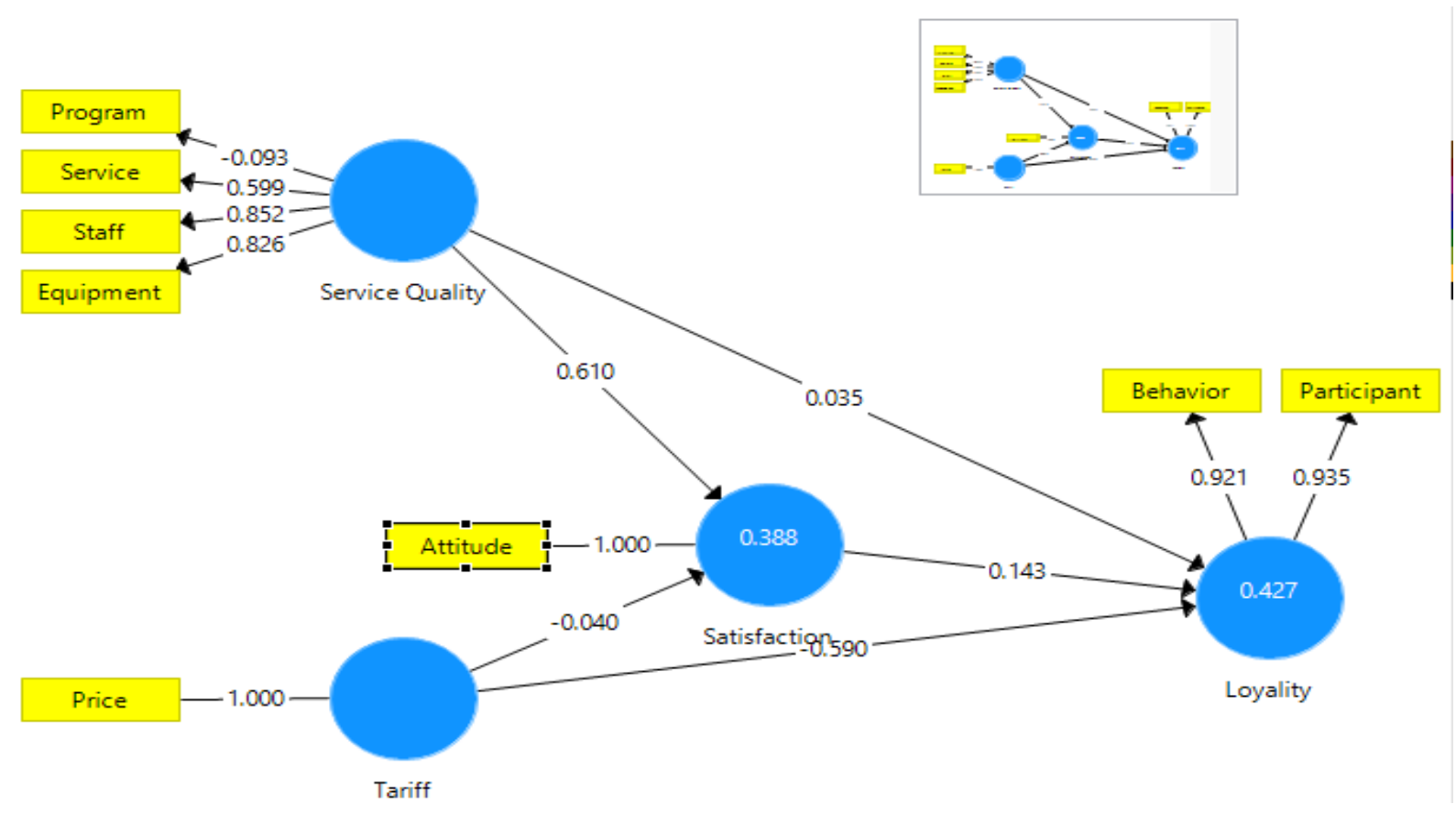

Diagram 2. The Research Structural Equation Modeling Result

This picture presents the relationship or correlation between indicators and variables, is there any influence from the indicator on the variable or the influence between variables themselves. From the results of the research obtained and based on the type of correlation like: a strong positive correlation from 1 to (0.5) and a strong negative correlation from -1 to $(-0.5)$ while the weak correlation is positive from between 0.5 to 0.00 and a weak negative correlation from -0.5 to 0.00 , this image showed the strong correlation between service, staff and equipment to the service quality. So the service quality is positively influenced by equipment (0.826), staff (0.852) and service
(0.599), nevertheless one of the service quality indicators: program, the result showed that there was a weak relationship or the luck of strong relationship between program and service quality showed the necessity of improving the schedule of the fitness in other to maintain the service quality.

The strong positive correlation between service quality and satisfaction $(0,610)$ showed the good management of the indicators of the service quality which indirectly positively influenced the satisfaction of the customers in the fitness. The behaviour loyalty was not directly influenced by the service quality with the weak negative 
correlation of $-0,093$; this one has been explained by the great amount of customers who were not satisfied by the program of the fitness.

The SEM showed a weak negative correlation between the tariff and the satisfaction of the customers $(-0.040)$, and also showed a strong negative correlation between tariff and behaviour loyalty $(-0.590)$. Whether strong negative or weak negative correlation it gave automatically idea that if the values of $\mathrm{X}$ or independent variable decrease the consequences the values of $\mathrm{Y}$ or dependent variable increase. What that's meaning in this case: The explanation is very simple, if the fitness decreases the ticket price, the customers will be satisfied to continue to visit that place..

\section{There is linear regression between dependent variable and independent variable.}

Linear regression is a common Statistical Data Analysis technique. In simple linear regression a single independent variable is used to predict the value of a dependent variable. Linear regression attempts to model the relationship between two variables by fitting a linear equation to observed data. A linear regression line has an equation of the form $\mathrm{Y}=\mathrm{a}+\mathrm{bX}$, where $\mathrm{X}$ is the explanatory variable and $\mathrm{Y}$ is the dependent variable. In this research the explanatory variable is the Tariff $(\mathrm{X})$, and the Satisfaction (Y1), Loyalty (Y2) dependent variables. With the software SPSS this research hypothesis have been verified:

H0: There are no relationships among variables: Tariff, Satisfaction, and Loyalty.

Ha: There are significant relationships between variables: Tariff, Satisfaction, and Loyalty.

According to the result below Diagram 3 and Table 3 showed a significant relationship between tariff and Loyalty with confidence interval of $5 \%$. The following Table 4 showed the strong positive correlation among the indicators- variables, and variable among themselves as the same it has been explained by SEM. The linear regression showed that if the price decreased certainly the customers will increase, finally for the paired samples correlations: pair 1, 2, 4, 5, 7, 8, and 9, H0 is reject and received Ha: the is a relationship between indicators- variable , and variable- variable except pair 3 and 6 characterized by the absent of relationship.

In general the study was centered on the search of the correlation which would be between indicators - variable, and the variables between themselves. The regression search allowed to see if the independent variables predict on the values of the dependent variables.

\section{Normal P-P Plot of Regression Standardized Residual}

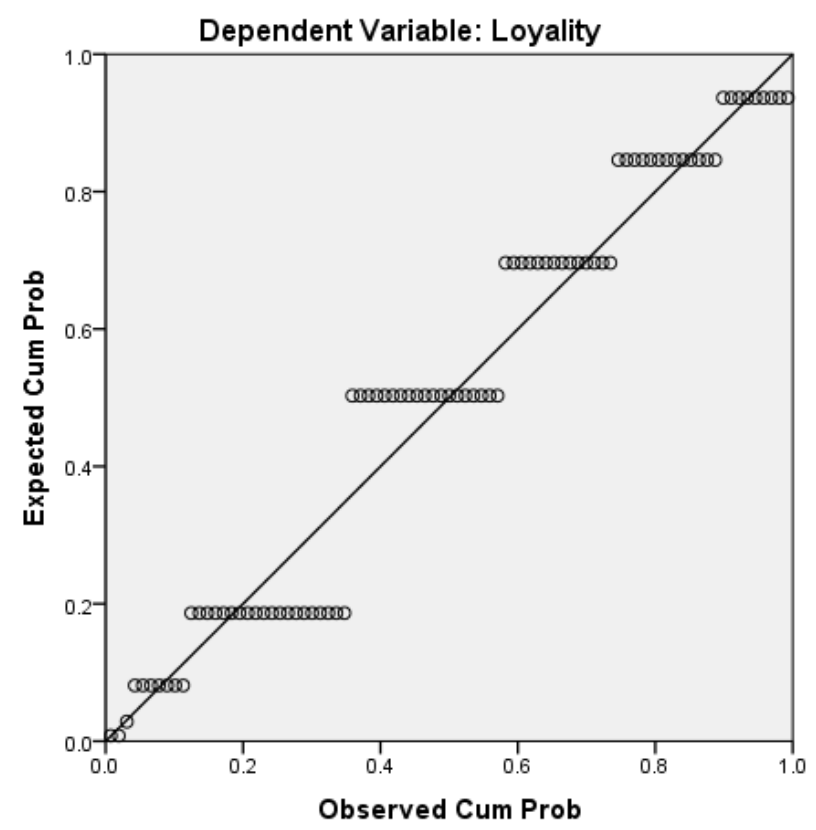

Diagram 3. Regression Standardized Residual Loyalty-Tariff

Table 3. Analyse Regression Tariff-Loyalty

\begin{tabular}{|c|c|c|c|c|c|c|}
\hline \multicolumn{7}{|c|}{ ANOVA $^{a}$} \\
\hline \multicolumn{2}{|c|}{ Model } & $\begin{array}{l}\text { Sum of } \\
\text { Squares }\end{array}$ & df & Mean Square & $\mathrm{F}$ & Sig. \\
\hline \multirow[t]{3}{*}{1} & Regression & 5.213 & 1 & \multirow{3}{*}{$\begin{array}{r}5.213 \\
.171\end{array}$} & \multirow[t]{3}{*}{30.470} & \multirow[t]{3}{*}{$.000^{\mathrm{b}}$} \\
\hline & Residual & 14.199 & 83 & & & \\
\hline & Total & 19.412 & 84 & & & \\
\hline \multicolumn{7}{|c|}{ a. Dependent Variable: Loyality } \\
\hline \multicolumn{7}{|c|}{ b. Predictors: (Constant), Tarif ini Rp } \\
\hline
\end{tabular}


Table 4. Significance testing results of the structural model path coefficients Correlation.

\begin{tabular}{|ll|r|r|r|}
\multicolumn{7}{|c|}{ Paired Samples Correlations } \\
\hline & & $\mathrm{N}$ & Correlation & \multicolumn{1}{c|}{ Sig. } \\
\hline Pair 1 & Equipment \& Service quality & 85 & .180 & .009 \\
Pair 2 & Staff \& Service quality & 85 & .218 & .045 \\
Pair 3 & Program \& Service quality & 85 & .183 & .093 \\
Pair 4 & Tarif ini Rp \& Satisfaction & 85 & -.225 & .039 \\
& Service quality \& & 85 & .518 & .000 \\
Pair 5 & Satisfaction & & & \\
Pair 6 & Service quality \& Loyality & 85 & .151 & .168 \\
Pair 7 & Satisfaction \& Loyality & 85 & .406 & .000 \\
Pair 8 & Participant \& Loyality & 85 & .722 & .000 \\
Pair 9 & Tarif ini Rp \& Loyality & 85 & -.518 & .000 \\
\hline
\end{tabular}

\section{Discussion}

The most important contribution of a research is to show how the auctions can be effectively operated by facilitating the service quality of auctioneer and seller. Yen, C., \& Lu, H. (2008) [19]. The proposed research model examines loyalty intention regarding trough satisfaction, service quality and tariff in the fitness. With the above statement, it can be seen the strong positive relationship among indicators and variables. Service quality directly influences customers' trust, service quality directly empirical customer loyalty, and customer trust measure the influence of service quality on customer loyalty Mahmud (2017) [20] As a result the Influence of Customer Satisfaction as an Intervening Variable between Service Quality and Customer Loyalty it has directly affected by the good management of service quality through its indicators. The results of original sample, Structural Equation Modeling (SEM) and linear regression Statistics calculations prove that there is a strong positive correlation and significant influence between service quality on customer satisfaction, and customer satisfaction on customer loyalty was not significant because of the tariff in the fitness was not moderated. However, behavioral loyalty is strongly negative influenced by the discomfort fitness rates or tariff. In today's turbulent economic environment service quality is an invaluable asset that business should manage in order to survive and gain a competitive advantage Kranias, A., \& Bourlessa, M. (2013) [21]. All hypotheses were verified and confirmed.

\section{Conclusions}

Based on the results of the research and discussion that have been put forward, conclusions can be drawn: a strong relationship among service quality on customer satisfaction at the Fitness Club has been demonstrated as the basic of increasing customers, nevertheless the high price negatively influenced the participation of customers in the fitness, the role of satisfaction in shaping users' continuance intention is very great to maintain the customers. Thus, service quality and tariffs become strong management tools that help sports managers to decide how to allocate resources to improve satisfaction, customer loyalty. Quality of service directly affects customer satisfaction. It can be said that customers will believe in the fitness UNY, if the fitness UNY increase attention to physical facilities, including update its program, service procedures, such as fitness employees in helping customers during the training, for example for the new comers , inform the customers appropriately, providing the service to the visitor sincerely (wholeheartedly), and to reduce the tariff. In addition, employees are able to create close family relationships and while communicating using empathy, where employees hear more when customers complain, so employees can dig deeper into customer wishes and complaints, which employees can then offer the solution.

\section{REFERENCES}

[1] Yildiz, S.M. \& Kara, A. (2012). A re-examination and extension of measuring perceived service quality in Physical Activity and Sports Centres (PSC): QSport-14 scale. International Journal of Sports Marketing \& Sponsorship, April.

[2] Santos, J. (2003). E-service quality: a model of virtual service quality dimensions. Managing Service Quality, 13(3), 233-246. http://dx.doi.org/10.1108/09604520310476 49

[3] Avourdiadou, S. \& Theodorakis, N.D. (2014). The development of loyalty among novice and experienced customers of sport and fitness centres. Sport Management Review, 17, 419-432

[4] Kim, P. \& Han, J. (2013). Effects of Job Satisfaction on Service Quality, Customer Satisfaction, and Customer 
Loyalty: The Case of a Local State-Owned Enterprise. WSEAS Transactions on Business and Economics, 10(1), 49-68

[5] Mosahab, R., Mahamad, O. \& Ramayah, T. (2010). Service Quality, Customer Satisfaction and Loyalty: A Test of Mediation. International Business Research, 3(4), 7280.

[6] Christian Grönroos, (2001) "The perceived service quality concept-a mistake?", Managing Service Quality: An International Journal, Vol. 11 Issue: 3, pp.150-152

[7] Nguyen, N., \& Leblanc, G. (2001).Corporate image and corporate reputation in customers' retention decisions in services.Journal of Retailing and Consumer Services, 8, 227-236.

[8] Olorunniwo, F., Hsu, M. K., \& Udo, G. J. (2006). Service quality, customer satisfaction and behavioural intentions in the service factory. Journal of Services Marketing, 20(1), 59-72.

[9] Soteriou, A. C., \& Stavrinides, Y. (2000). An internal customer service quality data envelope analysis model for bank branches. International Journal of Bank Marketing, 18(5), 246-252. http://dx.doi.org/10.1108/02652320010356 799

[10] Nusair, K., Yoon, H. J., Naipaul, S., \& Parsa, H. G. (2010). Effect of price discount frames and levels on consumers' perceptions in low-end service industries. International Journal of Contemporary Hospitality Management, 22(6), 814-835. http://dx.doi.org/10.1108/09596111011063106

[11] Zineldin, M. (2006). The quality of health care and patient satisfaction: An exploratory investigation of the 5Qs model at some Egyptian and Jordanian medical clinics. International Journal of Health Care Quality Assurance, 19(1), 60-92. http://dx.doi.org/10.1108/0952686061064260 9

[12] Payne, A. \& Frow, P. (2013). Strategic Customer Management: Integrating Relationship Marketing and CRM. New York, NY: Cambridge

[13] Seth, N., \& Deshmukh, S. G. (2005). Service quality models: a review. International Journal of Quality \& Reliability Management, 22(9), 913-949. http://dx.doi.org/10.1108/026 56710510625211

[14] Yeung, M. C. H., Ging, L., \& Ennew, C. T. (2002). Customer satisfaction and profitability: A reappraisal of the nature of the relationship. Journal of Targeting, Measurement and Analysis for Marketing, 11(1), 24-33. http://dx.doi.org/10.1057/palgrave.jt.5740064

[15] Szmigin, I. \& Carrigan, M. (2001). Wherefore customer loyalty? Journal of Financial Services Marketing, 6(1), [16]. Tiessen-Raaphorst, A. \& Broek, A. van den (2016). Sport en cultuur (Sport and culture),

[16] Pedragosa, V. \& Correia, A. (2009). Expectations, satisfaction and loyalty in health and fitness clubs. International Journal of Sport Management and Marketing, 5(4), 450-464 (PDF) The Impact of Perceived Service Quality on Customer Loyalty in Sports Clubs. Availablefrom

[17] Parasuraman, A., Berry, L. L., \& Zeithaml, V. A. (1993). Research Note: More on Improving Service Qualit
Measurement. Journal of Retailing, 69(1), 140 http://dx.doi.org/10.1016/S0022- 4359(05)80007-7

[18] Yen, C., \& Lu, H. (2008). Effects of e - service quality on loyalty intention: an empirical study in online auction. Managing Service Quality: An International Journal, 18(2), 127-146. doi:10.1108/09604520810859193

[19] Mahmud, U (2017).The Effect of Service Quality on Trust and Loyalty for Giant Customers in Malang Arab J Bus Manage Rev 2017, Vol 7(5): 322for Giant Customers in Malang

[20] Kranias, A., \& Bourlessa, M. (2013). Investigating the Relationship Between Service Quality and Loyalty in Greek Banking Sector. Procedia Economics and Finance, 5, 453-458. doi:10.1016/s2212-5671(13)00053-1 